\title{
Benefits of Use of Spur Gears with Asymmetric Profile
}

Jarmila Vojtková

Technical University of Košice, Faculty of Mechanical Engineering, Letná 9, 040-01 Košice, Slovakia

\begin{abstract}
Using of different angles for the left and right side allows creating a tooth with the beneficial parameters. The software was developed to control the shape of the teeth, for calculation of the reduced radii of curvature of the asymmetrical teeth, Hertz pressures, the pressure angles limits and specific sliding. The asymmetrical gearing is suitable mainly for one direction of rotation, and the pinion can, therefore, have a lower number of teeth. By comparing the values, one can determine the benefits of their application.
\end{abstract}

Keywords: involute curve, asymmetric tooth, specific sliding, pressure angle

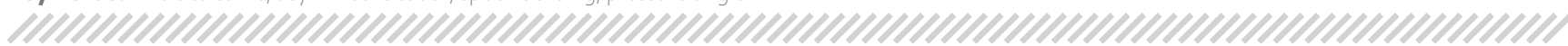

\section{Introduction}

Symmetrical teeth are commonly used for the entire spectrum of applications [3. 4]. Classical design of gears is based on the number of teeth and design module, the shape of basic rack is defined by the standard module and the pressure equal to $20^{\circ}$. The minimum number of teeth, for the normalized pressure angle, also depends on the addendum coefficient value. To improve the mesh conditions, various tooth corrections are mainly used. The most common type of correction is a correction by moving the tooth profile, and in case of helical gears, it is also a correction of helical angle. The majority of corrections are applied in order to achieve not only the desired centre-to-centre distance, but also to improve strength, stiffness properties of the teeth, or to remove the teeth undercutting or balance the specific sliding $[1-3,7,9]$.

\section{Asymmetric Teeth}

Involute curve changes its shape depending on the pressure angle (Fig. 1).

In Fig. 1, there are involute curves for pinions with a number of the teeth $z_{1}=17$, module $10 \mathrm{~mm}$ and selected angles $\alpha$ are $15^{\circ}, 20^{\circ}, 30^{\circ}, 40^{\circ}$.

An asymmetric involute tooth is formed by two involute curves. The involute curves satisfy the law of gearing. The mesh is only on the line of action. The tooth asymmetry is created by different values of the tooth pressure angle for the left side $\alpha_{\mathrm{L}}$ and the right side $\alpha_{\mathrm{P}}[1-3,6,7]$.

Autor korespondujący:

Jarmila Vojtková, jarmila.vojtkova@tuke.sk

Artykuł recenzowany

nadesłany 8.04.2016 r., przyjęty do druku 27.04.2016 r.

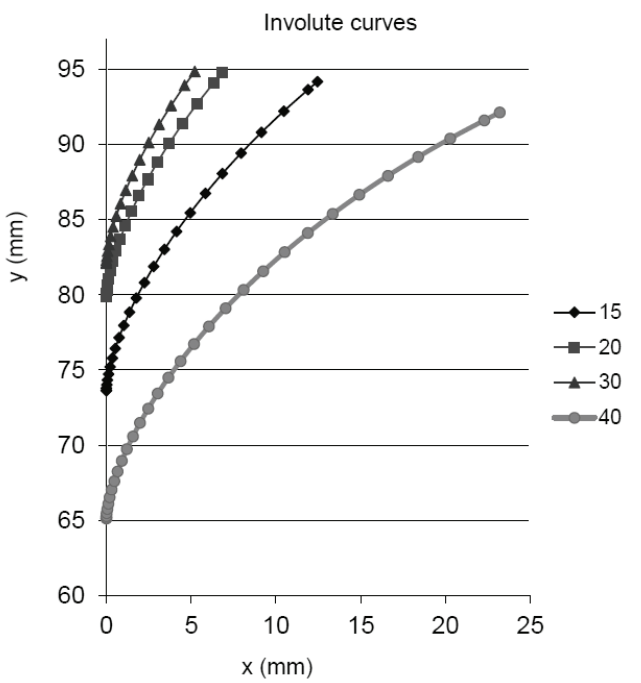

Fig. 1. Involute curves for a variety of pressure angles Rys. 1. Ewolwentowe profile zęba dla różnych kątów przyporu

Pictures in the article are made so that the left side is determined from the minimum number of teeth (i.e. defined by the angle $\alpha_{\mathrm{L}}$ ). The right side is determined by the condition of the maximum value of the angle $\alpha_{\mathrm{P}}$, taking into account that the total top land thickness is $\geq 0.25 \mathrm{~m}_{\mathrm{n}}$. At a fixed value of the left pressure angle, the right pressure angle can be from the interval $<\alpha_{\mathrm{L}}, \alpha_{\mathrm{P}}>$. The right involute can be between the curves 1 and 2 (Fig. 2b). As shown in Fig. 2c, it is possible to see a change relative to the symmetrical shape, the area 3 is removed and the area 4 , is added to the symmetrical shape. If, however, the left angle $\alpha_{\mathrm{L}}$ is increased, the right angle $\alpha_{\mathrm{p}}$ is decreased in order to comply with the condition of a sufficient top tooth thickness [1-3]. The limit values of pressure angles can be determined by using the custom made software (Fig. 5). Figure 3 presents a tooth segment with a large asymmetry, the number of the teeth of pinion $z_{1}=17$. Base circle is not identical for left and right sides. The base circle diameter is smaller for a bigger angle $\alpha$. 
In Fig. 4, there are the mesh and radii of curvature for a different direction of rotation. Points $N_{1}$ and $N_{2}$ are the interference points. As the radius of curvature increases, the pressure angle $\alpha$ increases also. The change of angle $\alpha$ leads to changes in the radii of curvature, which affects the Hertz pressures. Centre-to-centre distance stays the same.

The minimum number of teeth with allowed undercutting $z_{\min }^{\prime}$

$$
z_{\min }^{\prime}=\frac{5}{6} \cdot \frac{2 \cdot h_{a}^{*}}{\sin ^{2} \alpha}
$$

where: $h_{a}^{*}$ - tooth addendum coefficient, $\alpha$-pressure angle $\left(^{\circ}\right)$.

The radii of curvature at the first point of mesh $A$ (Fig. 4) for the tooth defined by pressure angle $\alpha_{\mathrm{L}}$ and $\alpha_{\mathrm{p}}$ are:

$$
\begin{gathered}
\rho_{1 A L}=\left(a \cdot \sin \alpha_{L}\right)-\sqrt{\left(r_{2}+h_{a}^{*} \cdot m\right)^{2}-\left(r_{2} \cdot \cos \alpha_{L}\right)^{2}} \\
\rho_{1 A P}=\left(a \cdot \sin \alpha_{P}\right)-\sqrt{\left(r_{2}+h_{a}^{*} \cdot m\right)^{2}-\left(r_{2} \cdot \cos \alpha_{P}\right)^{2}}
\end{gathered}
$$

where: $m$-module $(\mathrm{mm}), r_{2}$ - pitch radius of the wheel $(\mathrm{mm})$, $a$ - centre distance $(\mathrm{mm})$.

Specific sliding of pinion for the left side is:

$$
\vartheta_{1 A L}=\frac{\rho_{1 A L} \cdot \omega_{1}-\rho_{2 A L} \cdot \omega_{2}}{\rho_{1 A L} \cdot \omega_{1}}
$$

where: $\vartheta_{1 A L}-$ specific sliding at the first point $A$ of the mesh, $\alpha_{\mathrm{L}}-$ pressure angle $\left({ }^{\circ}\right), \omega_{1}$ - input angular velocity $(\mathrm{rad} / \mathrm{s})$, $\omega_{2}$ - output angular velocity $(\mathrm{rad} / \mathrm{s}), \rho_{1 A L}$ - radius of curvature at the point $A$.

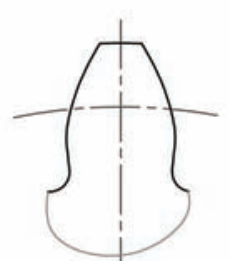

a)

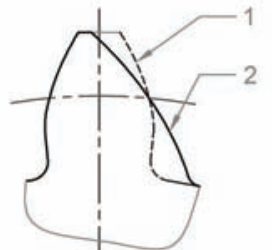

b)

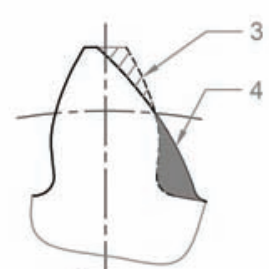

c)
Fig. 2. Tooth shape: a) symmetrical tooth, b) asymmetric tooth, c) 3 - Area where material is removed, $4-$ area where material is added

Rys. 2. Kształt zęba: a) ząb symetryczny, b) ząb asymetryczny, c) 3-strefa z usuniętym materiałem, 4 - strefa $z$ dodanym materiałem
A formula for specific sliding at point $A$ for the right side is analogical to formula (4).

\section{Software for Control and Analysis}

The software (Fig. 5, Fig. 6) was developed to address the issue with asymmetric teeth, it allows to check and compare the following important parameters:

- design of a pinion without undercutting,

- design of a pinion with allowed undercutting,

- contact ratio,

- calculation of the radii of curvature and their reduced values,

i.e. basic characteristics of the calculation of Hertz pressures,

- pressure angles limits,

- specific sliding for pinions.

For asymmetric teeth, it is required to follow more parameters simultaneously. For given parameters, several separate profiles can be created.

The software has a number of work modes. In every work mode, a different number of parameters can be defined.

The software draws graphs for pressure angle limits (Fig. 5). It draws graphs for specific sliding separately for right and left sides (Fig. 6). It controls the value of contact ratio (must be larger than one). It controls sufficient top land thickness. It also calculates values of radii of curvature at different mesh points and draws their reduced values. The software checks possible interferences.

The important benefit of asymmetric tooth profile applications is mainly a significant reduction in specific sliding

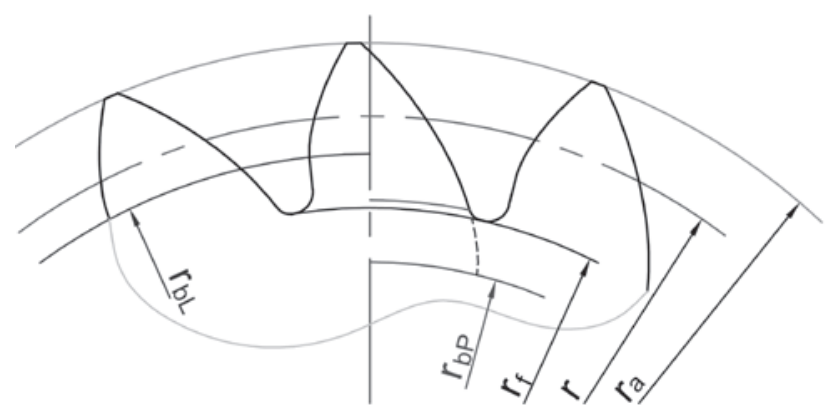

Fig. 3. Segment of the pinion, $z_{1}=17, \alpha_{L}=20^{\circ}, \alpha_{p}=39.5^{\circ}$ Rys. 3. Segment wałka zębatego, $z_{1}=17, \alpha_{L}=20^{\circ}, \alpha_{p}=39,5^{\circ}$
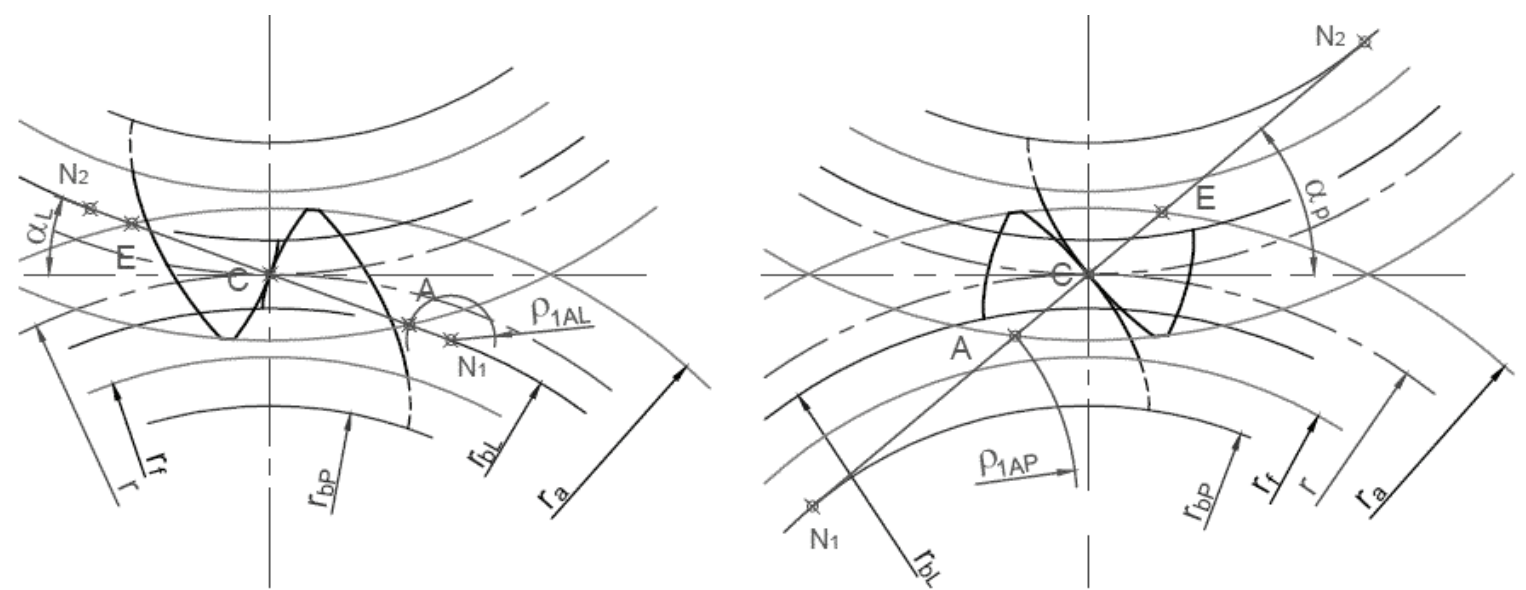

Fig. 4. Mesh of asymmetric teeth: a) driving side $\left.\alpha L=20^{\circ}, b\right)$ driving side $\alpha P=35^{\circ}$

Rys. 4. Zazębienie zębów asymetrycznych: a) strona napędowa dla $\alpha \mathrm{L}=20^{\circ}$, b) strona napędowa $\alpha \mathrm{P}=35^{\circ}$ 


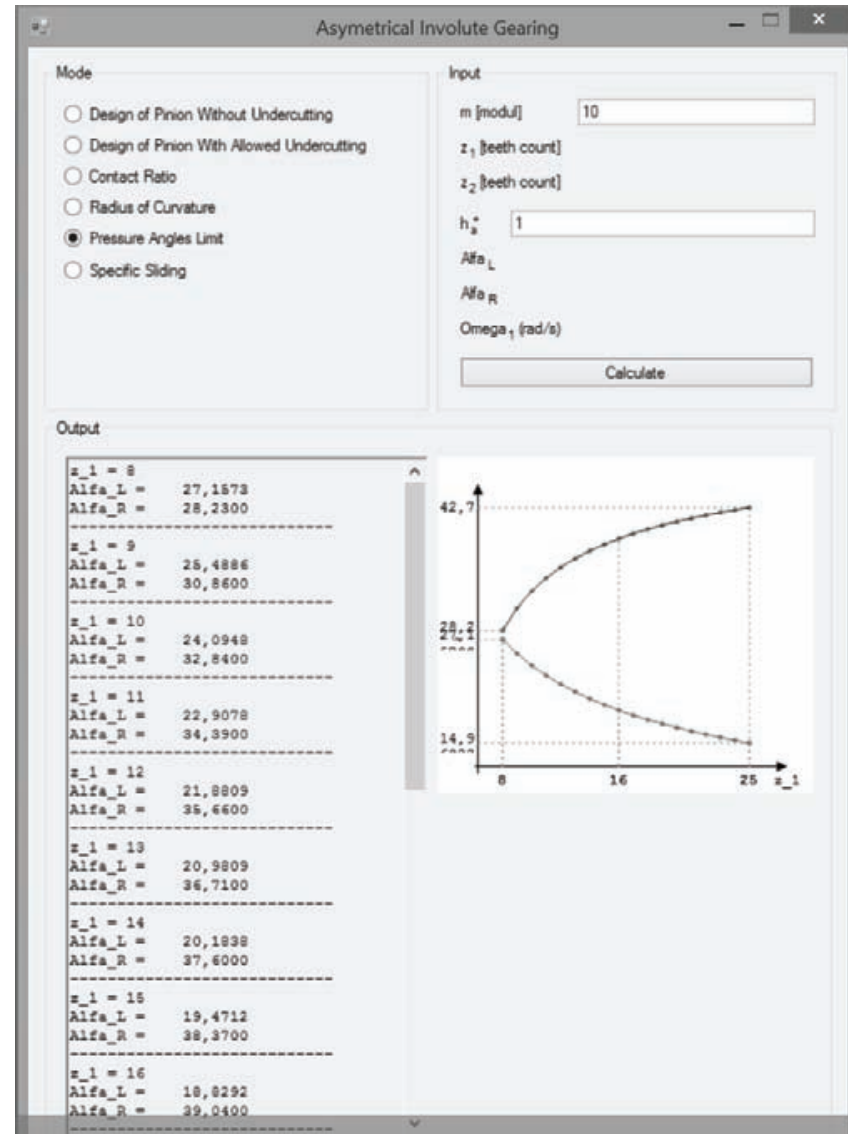

Fig. 5. The software for the control and analysis of asymmetric teeth, pressure angles limits for the left side and right side

Rys. 5. Oprogramowanie do sprawdzania i analizy zębów asymetrycznych, kątów granicznych przyporu dla strony lewej i prawej

and Hertz pressures at the point of the first contact of the teeth. Fig. 7 , specific sliding is a function of the pressure angle $\alpha$. The left side is defined by standard value of $20^{\circ}$.

In the Tab. 1 the values for examined parameters by different number of the teeth $z_{1}$ are listed.

Tab. 1. Specific sliding and radii of curvature for gear ratio equal to 1 one and $h^{*}=1$

Tab. 1. Średnie poślizgi i promienie krzywizny dla przełożenia równego 1 i współczynnika $h_{a}^{*}=1$

\begin{tabular}{|c|c|c|c|c|c|c|}
\hline$z_{1}$ & $\alpha_{\mathrm{L}}\left({ }^{\circ}\right)$ & $\vartheta_{1 \mathrm{AL}}$ & $\rho_{1 \mathrm{AL}}(\mathrm{mm})$ & $\alpha_{\mathrm{P}}\left({ }^{\circ}\right)$ & $\vartheta_{1 \mathrm{AP}}$ & $\rho_{1 \mathrm{AL}}(\mathrm{mm})$ \\
\hline 8 & 27 & -27.03 & 1.25 & 28 & -15.35 & 2.17 \\
\hline 11 & 22 & -43.70 & 0.90 & 34 & -2.05 & 15.19 \\
\hline 14 & 20 & -18.37 & 2.35 & 37.5 & -1.08 & 27.64 \\
\hline 17 & 18 & -17.95 & 2.63 & 39.5 & -0.74 & 39.41 \\
\hline 20 & 17 & -12.21 & 4.12 & 40.5 & -0.58 & 50.41 \\
\hline
\end{tabular}

\section{Conclusion}

The asymmetry allows to decrease number of the teeth on the pinion. The assymmetric teeth make it possible to decrease the gearing dimensions and to reduce weight. The course of specific sliding is advantageous especially for larger pressure angles. However, a disadvantage may be a lower value of contact ratio.

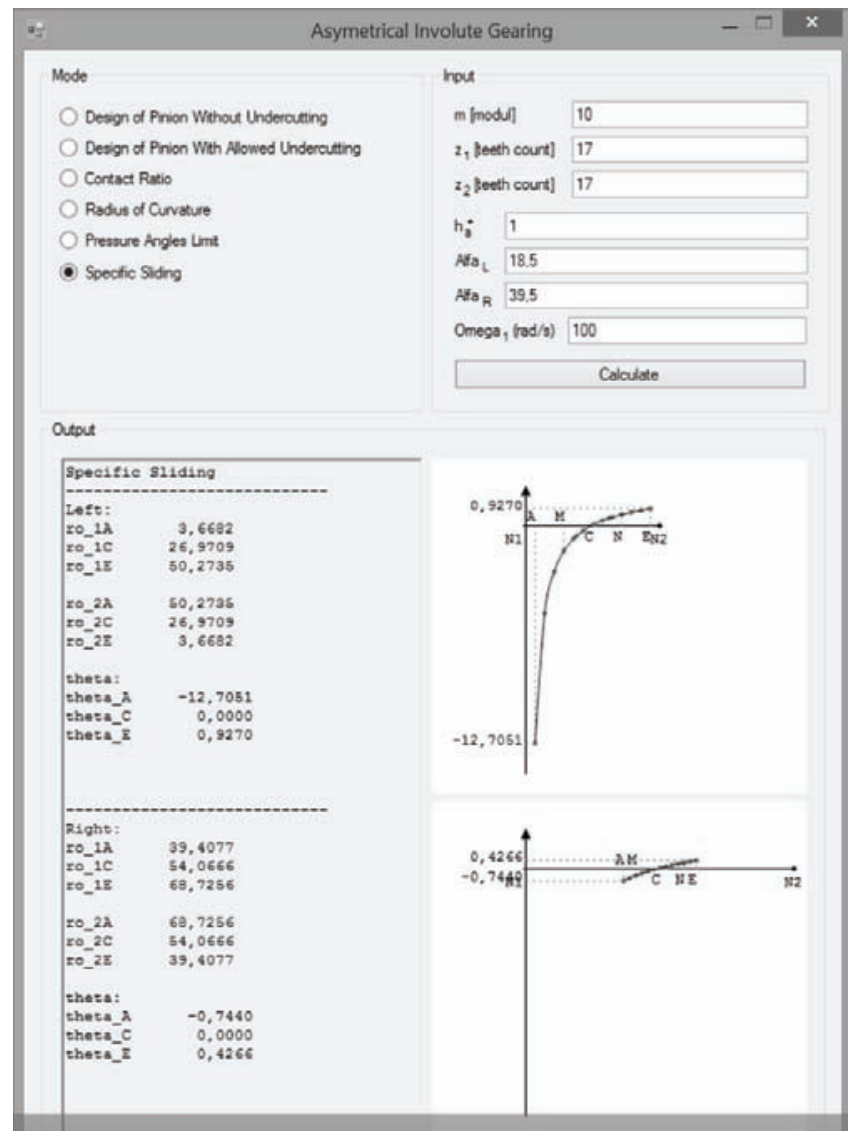

Fig. 6. The course of specific sliding, above, for driving side $\alpha_{1}=18.5^{\circ}$, below, for driving side $\alpha_{\mathrm{p}}=39.5^{\circ}$

Rys. 6. Przebieg średnich poślizgów, u góry dla strony napędowej o kącie $\alpha_{L}=18,5, u$ dołu dla strony napędowej o kącie $\alpha_{P}=39,5^{\circ}$

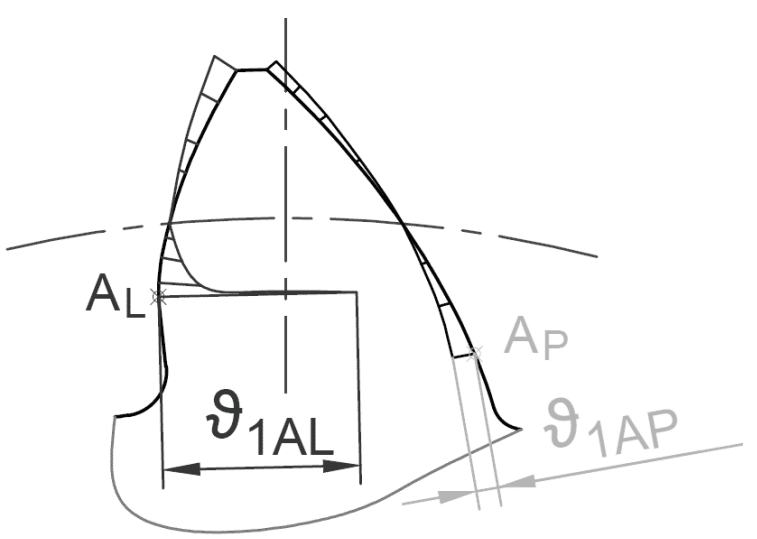

Fig. 7. The course of specific sliding on the involute tooth profile with the first point of mesh A defined for $z_{1}=17, \alpha_{1}=20^{\circ}, \alpha_{p}=39.5^{\circ}$ Rys. 7. Przebieg zmian poślizgu na profilu ewolwentowym zęba dla pierwszego punktu zazębienia A określonego przez $z_{1}=17, \alpha_{L}=20^{\circ}$, $\alpha_{p}=39,5^{\circ}$

The software mentioned herein allows quick and comfortable monitoring of asymmetric teeth. This gearing may be used only if the cost is not the ultimate criterion.

\section{Acknowledgment}

This paper was written within the framework of Grant Project VEGA: „1/0688/12 - Research and application of universal regulation system in order to master the source of mechanical systems excitation". 


\title{
Bibliography
}

1. Vojtková J., Reduction of contact stresses using involute gears with asymmetric teeth, "Scientific Journal of Silesian University of Technology. Series Transport". Vol. 89 (2015), 179-185.

2. Vojtková J., Čelné ozubené kolesá s priamymi zubami s asymetrickým profilom - návrh a trvanie záberu, 51. Medzinárodná vedecká konferencia katedier častí a mechanizmov strojov, Zborník referátov: 8-10.9.2010, Košice - Slovenský Raj - Košice: CPRESS, 2010.

3. Vojtková J., Effect of asymmetry on radii of curvature for spur gears with nonsymetrical teeth. "Zeszyty Naukowe Politechniky Śląskiej", Vol. 84, No. 1907, 2014, 47-51.

4. Czech P. et al., The influence of noise on the car ride comfort, "Logistyka", No. 4 (2015).

5. Sapieta M., Dekýš V., Pastorek P., Using of activ thermography and lockin method with ultrasound excitation for detection of material defect, "Zeszyty Naukowe Politechniki Śląskiej", Vol. 84, No. 1907/2014, 119-124.
6. Homišin J., Kaššay P., Čopan P., Possibility of torsional vibration extremal control, "Diagnostyka", Vol. 15, No. 2/2014, 7-12.

7. Czech P., Mikulski J., Application of Bayes classifier and entropy of vibration signals to diagnose damage of head gasket in internal combustion engine of a car, "Communications in Computer and Information Science", Vol. 471/2014, $225-232$.

8. Di Francesco G., Marini S., Asymmetric teeth: Bending stress calculation, March/April 2007 [http://www. geartechnology.com].

9. Czech P., Łazar B., Wojnar G., Wykrywanie lokalnych uszkodzeń zębów kót przekładni z wykorzystaniem sztucznych sieci neuronowych $i$ alogorytmów genetycznych, Bibioteka Problemów Eksploatacji, Radom 2007.

Streszczenie: Zastosowanie różnych kątów dla lewej i prawej strony zęba pozwala na stworzenie kształtu o odpowiednich parametrach. Opracowane oprogramowanie umożliwia: ustalić właściwy kształt zęba oraz obliczyć zredukowane promienie krzywizny dla zębów asymetrycznych, naciski Herza, kąty graniczne profili oraz średnie poślizgi. Porównanie tych wartości pozwala określić zalety stosowania tego rodzaju profili asymetrycznych.

\section{Ing. Jarmila Vojtková, PhD}

\author{
jarmila.vojtkova@tuke.sk
}

Graduated in 1982 from Technical University in Košice - specialised in the field of Transport Machinery and Operation Equipment. Doctor of Engineering - expert in Parts of Machines. In her scientific work, she solves the issues of special gearing, toroidal drives and asymmetrical teeth. Author of 70 publications.

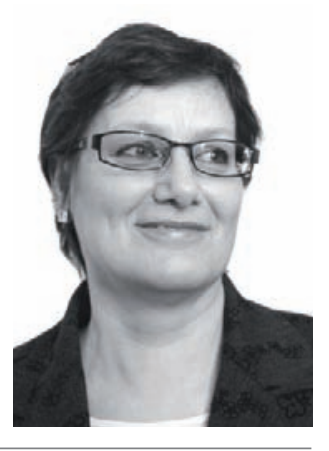

